\title{
A Prospective Study on Medication Errors in an Intensive Care Unit
}

\section{Yoğun Bakım Ünitesinde İlaç Hataları Üzerine Prospektif Bir Çalışma}

\author{
(D) Khayati MOUDGIL1*, (D) Bhagya PREMNATH2, (D) Jemi Rachel SHAJI2, (D) Indhrajith SACHIN2, (D) Samrin PIYARI2 \\ ${ }^{1}$ Faculty of Health Sciences, School of Pharmacy, JSS Academy of Higher Education \& Research, Vacoas, Republic of Mauritius \\ 2JSS College of Pharmacy, Ooty. JSS Academy of Higher Education and Research, Mysuru, India
}

\begin{abstract}
Objectives: Any preventable event related to drugs that may cause harm to a patient is known as "medication error". Errors occur due to a lack of knowledge, poor performance, and psychological lapses. The pharmacists has a major role along with physicians, nurses, and administrators to examine and improve the healthcare system in order to ensure patient safety. The objective of this study was to determine the frequency, causes, and types of medication errors in the secondary-care intensive care unit.

Materials and Methods: All medical records of intensive care unit patients, above 14 years of age, listing their co-morbid/non-co-morbid conditions, occupation, caste, and gender, were checked for medication errors for a period of 6 months at Government Head Quarters Hospital, Udhagamandalam. Results: According to the results of this study, 116 medication errors were found in 103 patients in the intensive care unit. The number of medication errors was higher in men than in women. The most common medication errors were prescription errors, which were due to illegible handwriting; the use of lookalike drugs; and incomplete dose, dosage, and frequency.

Conclusion: Considering the results of this study, it is important to increase awareness among healthcare professionals of varying stature about the significance of medication errors. It is also necessary to change the existing prescribing techniques and clearly differentiate lookalike drugs to avoid medication errors.
\end{abstract}

Key words: Error, drug, prescription

ÖZ

Amaç: Hastada ilaca bağlı zarar oluşturabilecek her önlenebilir hata "ilaç hatası” olarak bilinir. Hastalar bilgi eksikliği, düşük performans ve psikolojik sorunlar nedeniyle ortaya çıkabilir. Eczacıların doktor, hemşire ve yöneticilerle birlikte hasta güvenliğini sağlamak üzere sağlık sistemini geliştirmede büyük rolleri vardır. Bu çalışmanın amacı yoğun ikincil bakım ünitelerinde ilaç hatalarının sıklığı, nedenleri ve tiplerini belirlemektir.

Gereç ve Yöntemler: On dört yaş üzerindeki tüm yoğun bakım hastalarının komorbid/non-komorbid durumları, işleri, kastı ve cinsiyeti liste edilerek 6 ay içinde Udhagamandalam Devlet Merkez Hastanesi'ndeki ilaç hataları kontrol edilmiştir.

Bulgular: Çalışmanın sonuçlarına göre, yoğun bakımdaki 103 hastada 116 ilaç hatası bulunmuştur. Kadınlarda ilaç hatalarının sayısı erkeklere göre yüksektir. En sıklıkla rastlanan ilaç hataları okunamayan el yazısı ve benzer isme sahip ilaçlar nedeniyle ortaya çıkan yanlış ilaç verme, tam olmayan dozlama, dozajlama ve uygulama sıklığı hatalarıdır.

Sonuç: Çalışmanın sonuçları dikkate alındığında ilaç hataları hakkında farklı konumlardaki sağlık profesyonelleri arasında duyarlılı̆ı artırmanın önemli olduğu görülmektedir. Ayrıca, var olan reçeteleme tekniklerini değiştirme ve benzer özelliklerdeki ilaçları belirgin bir şekilde ayrıştırma ilaç hatalarını önlemek için gereklidir.

Anahtar kelimeler: Hata, ilaç, reçete 


\section{INTRODUCTION}

The term medication error can be described as improper/ incorrect administration of a medication that occurs due to an incorrect dosage or route of administration, failure to prescribe or administer the appropriate medication or formulation for a specific disease or condition, use of obsolete medicines, failure to follow the correct time to administer the medication or lack of knowledge of adverse effects. Causes of prescription errors include difficulty reading handwritten instructions, misunderstanding about different medications with similar names, and lack of knowledge about allergies or sensitivities to a patient's prescription. Drug errors occur when a patient is selected by a health care provider for an inadequate form of treatment. This is one of the main issues, and the correction of drug errors is the first step towards improving patient health. In this, the clinical pharmacist, along with health care practitioners, will play a significant role in patient safety. Errors in drug administration can be considered as lethal as any disease. Harvard University reported in a 2013 report that each year India reports a whopping 52 lakh accidents (out of the 430 lakhs worldwide) due to medical errors and adverse events (May 5, 2016). The key explanation for this is the lack of interaction amongst health care professionals.

A drug error can be categorized as (1) a prescription error, (2) an interpretation/transcription error, (3) an administration error, or (4) a documentation error.

1. Prescription error: An error made by the doctor while writing a prescription, such as poor handwriting, incorrect spelling of medications, incorrect dosage type, and no drug strength specified on the prescription. For example, the drug name is specified correctly, but the dosage type or frequency is not. This type of error can be fatal.

2. Transcription error: A form of error created by nurses and physicians when entering the specifics of the medication in the system or in the patient's profile. Errors in this category include double drug entry, absence of drug entry, or entry of a drug that was not administered.

3. Administration error: The most common error made by nursing staff during patient administration of medications. Such errors include prescribing the medications to the wrong patient, incorrect prescription, directions, dosage, indications, cause, time, duration, etc.

4. Documentation error: Patient care nurses play a significant role. Records of the patient's prescription history are kept by nurses. Mistakes in reporting details of the drug, such as no recording of the drug, double entry of the medications, or losing critical information when reporting, are known as documentation errors.

The main causes of medication error are missing patient information, missing drug information, miscommunication of a drug order, lack of education of nurses, lack of drug details from the patient's side, improper drug storage, illegible handwriting, incorrect drug selection, drug interactions, improper training of nurse's, etc.'
The following control measures can reduce the severity of medication error:

a. Ensuring proper drug administration to the correct patient, such as the correct medication, dose, path, and duration.

b. Following proper reconciliation of the medication when moving a patient from one unit to another, verifying the appropriate drug, dose, path, and time for the appropriate patient against the order of transfer.

c. Having nurses who work different shifts check prescription orders two or three times.

d. Ensuring proper preservation of records and documents.

e. Maintaining proper medicinal.

f. Avoiding the use of abbreviations.

\section{Types of prescription error:}

Computerized pharmacy order entry (CPOE) is a very helpful way for doctors to enter medication directly into a hospital's computer system that avoids poor handwriting to complete all vital details and can reduce the rate of medicine error. The use of this system will strengthen contact efforts during care transition. Doctors should be interested in tailoring CPOE to ensure that it is both user friendly and unique to their medical ordering needs. ${ }^{2,3}$ In addition to providing essential reminders and warnings, the computerized decision support systems can improve the clinical performance related to prescribing practices. It includes a summary of the orders as they are issued, comparing new and current orders, scanning for potential drug reactions, correct dosing schedules, and alerting the physician to appropriate laboratory results, all of which affect the physician's decisions and the patient care plan. ${ }^{4}$

Pharmacist-aided rounds ensure that medications are used rationally and cost effectively, facilitate safe living, and enhance clinical outcomes by regularly participating in direct patient care and partnering with other healthcare practitioners, thus reducing prescription errors. The use of CPOE can help to remove handwriting errors that can result in adverse effects on the patient. By using CPOE, we can prevent errors introduced by handwritten abbreviations, drug names, dosages, and frequencies. Abbreviations are one of the main causes of prescription drug errors when doctors write prescriptions by hand. Therefore, to prevent prescription errors, we must stop using abbreviations for product names, doses etc. The decimal point should be used with a leading zero so the patient or caretaker does not miss the decimal point on the prescription. For example; write $0.1 \mathrm{mg}$ drug instead of writing $1 \mathrm{mg}$.

Electronic order transcription with CPOE improves transcription speed and accuracy. Therefore, we can eliminate a few prescription mistakes using this. ${ }^{5}$ Mishearing often leads to the use of incorrect words or terms due to poor listening. To prevent this form of mistake, the pharmacist should be attentive to the doctors' orders. Security is the primary concept upon which verbal commands are recognized. Verbal directives have a greater potential for errors because such instructions may be misunderstood, misinterpreted, and mistranscribed. ${ }^{6}$ The patient's written documentation records are essential to 
the preparation and assessment of procedures and patient care. The written reports include the patient's medical history and drug history, the patient's course of treatment, care, and reactions while under the health care provider's supervision. ${ }^{7}$ Many of the good documentations can be reliable, complete, timely, truthful, and structured. Patient data, such as name, title, and other information, must be cross-checked with the medical record registry by the pharmacist or nurses before administration of the drug to the patient. ${ }^{8}$ A pharmacist must verify the appropriate dosage, route, and time written on the prescription before drug administration. ${ }^{9}$ Drug reconciliation is a procedure to strengthen communication so that mistakes can be avoided by obtaining the patient's medication history and reconciling the medication as soon as possible when the patient is admitted to hospital. The drug records will be reconciled with the hospital's discharge medicines. This is one of the best ways to prevent mistakes in recovery, such as when a patient is given their list of medications on hospital admission, thus decreasing likelihood of errors and harm. A medication reconciliation strategy that includes healthcare providers and patients can minimize medication morbidity and mortality and is a vital factor in patient safety. ${ }^{10-12}$

\section{MATERIALS AND METHODS}

The study was performed at government headquarters hospital, Ooty over a span of six months as a prospective analysis involving purposeful sampling. The criteria for inclusion in the research included all patients admitted to the intensive care unit, patients over 14 years of age, patients with co-morbid or non-comorbid conditions who belonged to any occupation, caste, or gender. The exclusion criteria covered pregnant or lactating mothers and patients under 14 years of age. The resources used for the research were patients' medical histories and types of drug errors (method of data collection). The drug error form was developed with the assistance of a healthcare professional. Forms were printed and kept in the ICU for the reference of healthcare professionals. Patients clinical histories were checked, and regular patient interviews were performed. Once the incidence was confirmed, the medication error was filed and documented. Institutional Review Board Ethical Approval was obtained for the study (JSSCP/IEC/ 01/2018-19).

\section{Statistical analysis}

No statistical analysis was carried out in this study.

\section{RESULTS}

A total of 116 drug errors were discovered among 103 patients according to the findings of this report. Considering the type of error, prescription errors were found to be more frequent than other errors, such as administration errors, paperwork errors, and transcription errors shown in Figure 1. Illegible handwriting was the main cause of medication error. The use of lookalike drugs and incomplete dose, dosage, and frequency information were other features, as outlined in Figure 2. The number of drug errors was higher in men than in women, as seen in Figure 3. The cardiovascular system was the most affected system
(Table 1). For this analysis, the age groups 55-64 years and 4554 years were the most affected (Table 2 ).

\section{DISCUSSION}

Medication errors are a major concern in many healthcare settings. This can have serious implications for patients and healthcare providers alike. It contributes to extended hospital stays with detrimental impacts. The main objective of this

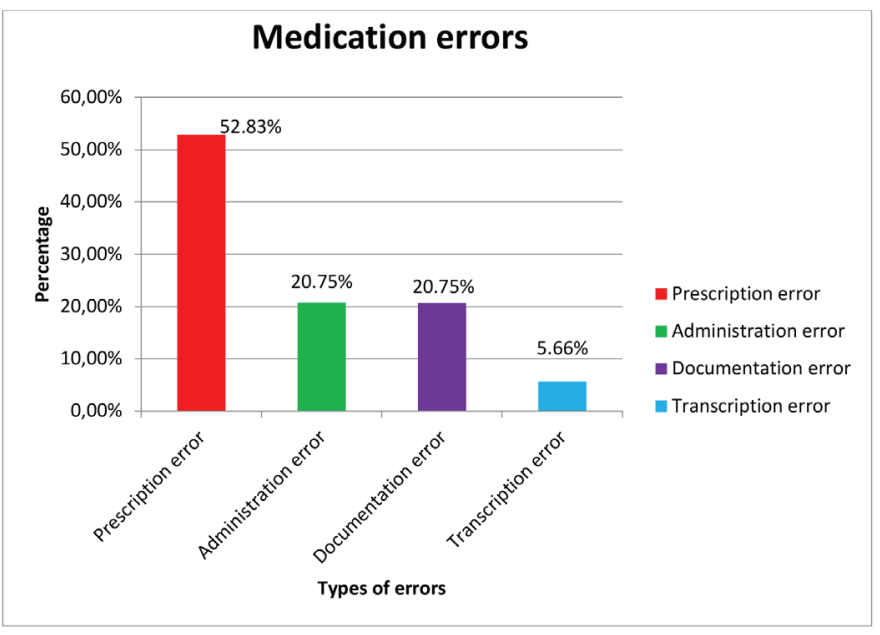

Figure 1. Type of medication errors

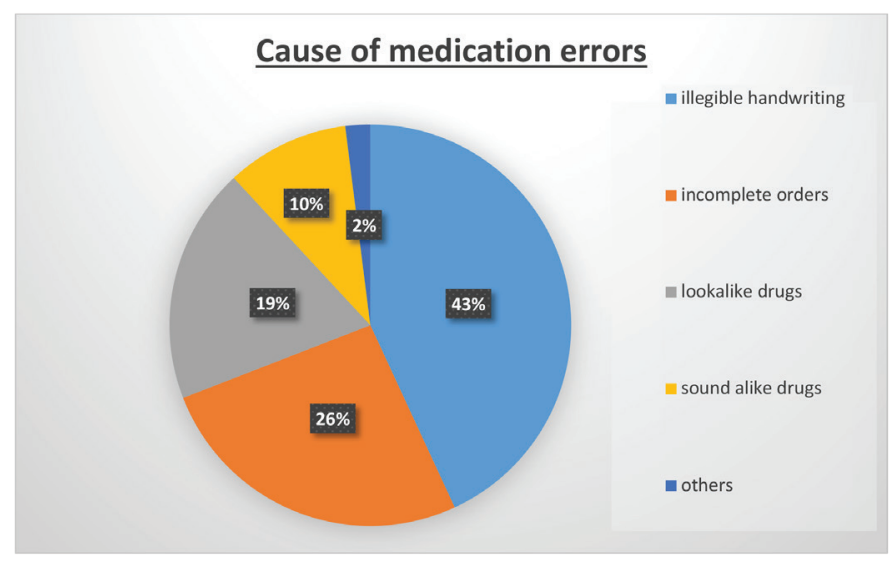

Figure 2. Causes of medication errors

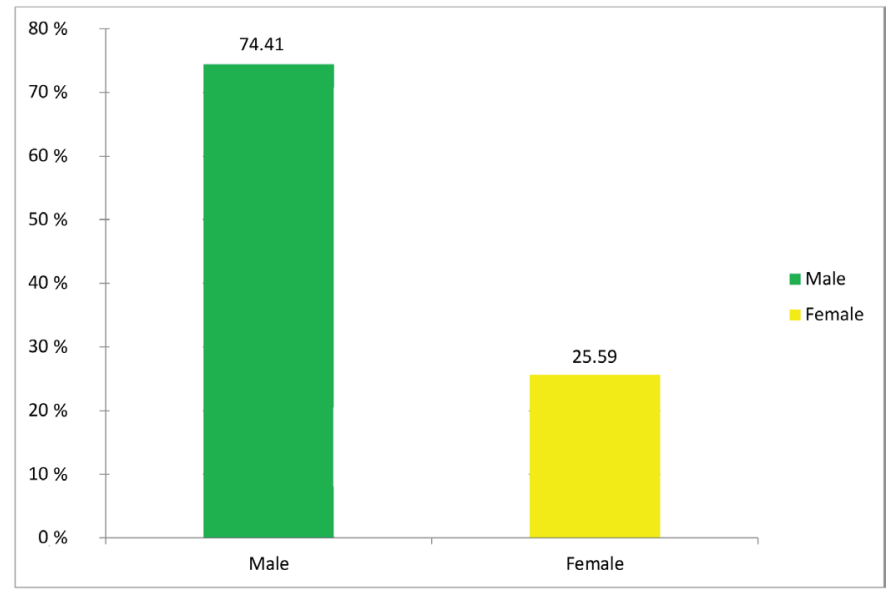

Figure 3. Male predominance of the effect of medication error 
research was to determine the prevalence of medication errors in an intensive care unit with patient safety as the goal by defining and reducing the major cause of medication errors to recognize various forms of medication errors and to raise awareness among health care professionals about medication errors.

The goal of drug treatment is to optimize the clinical outcome and enhance the patient's overall quality of life. Drug mistakes, however, have major consequences for safety. These errors may occur at various stages of drug usage, such as prescribing, dispensing, and administration. Early identification of these errors is of great importance for patient health. The most common source of medication error in the current study was prescription error at $52.83 \%$, followed by administration and reporting error at $20.75 \%$, and lastly, transcription error at $5.66 \%$. Published research papers show that not every drug error causes harm. Hospitals need to build and create mechanisms to avoid medication errors by identifying and recognizing the cause of such errors. Pharmacists must collaborate actively with doctors, nurses, and other personnel to ensure that medication prescriptions are safe and correct. The patient's medication files were consulted in the current study, and reports of errors were produced. The study emphasizes the importance of recording errors in developing prevention approaches aimed at minimizing medication errors.

\section{CONCLUSION}

Defining the characteristics and patterns of medication error can direct error prevention. Patients with life-threatening diseases

Table 1. Systems affected by medication error

\begin{tabular}{lll} 
& System & No of cases \\
\cline { 2 - 3 } Affected systems & Digestive & 17 \\
\hline & Cardiovascular & 43 \\
\cline { 2 - 3 } & Muscular & 13 \\
\cline { 2 - 3 } & Nervous & 6 \\
\hline Respiratory & 19 \\
\hline Excretory & 5 \\
\hline
\end{tabular}

Table 2. Effect of medication error on the cardiovascular system by age group

\begin{tabular}{lll} 
& \multicolumn{1}{c}{ Years } & Percentage \\
\cline { 2 - 3 } 15-24 & $25-34$ & 2.0 \\
\cline { 2 - 3 } Age group & $35-44$ & 6.97 \\
\cline { 2 - 3 } & $45-54$ & 12.0 \\
\cline { 2 - 3 } & $55-64$ & 23.25 \\
\hline & $65-74$ & 27.88 \\
\cline { 2 - 3 } & $75-84$ & 18.60 \\
\cline { 2 - 3 } & $85-94$ & 4.65 \\
\hline
\end{tabular}

are treated in intensive care units. The intensive care unit atmosphere produces potentially high-risk iatrogenic events. Critically ill patients, due to their underlying comorbidities and acute organ dysfunction, are particularly vulnerable to drug errors. Identifying medication errors is thus critical for reporting and preventing this risk. Perhaps more than one would expect, the underlying causes of medication error are in need of fundamental changes in healthcare systems. Additionally, the current prescription methods need to be updated and lookalike drugs specifically distinguished to prevent medication errors. One of the required improvements is to include pharmacists in the healthcare team and use their experience to mitigate medication error. Knowledge campaigns for healthcare professionals should be implemented and, likewise, awareness of the serious side effects of drugs and how to manage them should be provided to lay people. There is an urgent need for a systemic approach to reducing organizational vulnerability to errors by providing the tools needed to track, assess, and execute successful interventions.

\section{ACKNOWLEDGMENTS}

We would like to acknowledge the staff of government headquarters hospital, Ooty for their kind support and cooperation. We thank our HOD Dr. S. Ponnusankar for his immense support and guidance. It is hoped that all stakeholders will benefit from this study through revising processes that will lead to reducing the number of medication errors.

Conflicts of interest: No conflict of interest was declared by the authors. The authors alone are responsible for the content and writing of the paper.

\section{REFERENCES}

1. Sokol DK, Hettige S. Poor handwriting remains a significant problem in medicine. J R Soc Med. 2006;99:645-646.

2. Bates DW, Leape LL, Cullen DJ, Laird N, Petersen LA, Teich JM, Burdick E, Hickey M, Kleefield S, Shea B, Vander Vliet M. Effect of computerized physician order entry and a team intervention on prevention of serious medication errors. JAMA. 1998;280:1311-1316.

3. Bates DW, Teich JM, Lee J, Seger D, Kuperman GJ, Ma'Luf N, Boyle $D$, Leape L. The impact of computerized physician order entry on medication error prevention. J Am Med Inform Assoc. 1999;6:313-321.

4. Kuperman GJ, Gibson RF. Computer physician order entry: benefits, costs, and issues. Ann Intern Med. 2003;139:31-39.

5. Sokol AJ. Financial benefits of electronic medical records. EHealth Coach Monthly Oct 2001. Last Accessed Date: 15.10.2003. Available from: www.ehealthcoach.com/FR-FinBenElecMedRec.asp

6. Briggs B. CPOE order from chaos. Health Data Manag. 2003;11:44-48.

7. Pronovost P, Weast B, Schwarz M, Wyskiel RM, Prow D, Milanovich SN, Berenholtz S, Dorman T, Lipsett P. Medication reconciliation: a practical tool to reduce the risk of medication errors. J Crit Care. 2003;18:201205.

8. Patel S, Patel A, Patel V, Solanki N. Study of medication error in hospitalised patients in tertiary care hospital. Int $\mathrm{J}$ Pharm Pract. 2018;11:32-36. 
9. Grissinger M. Oops, sorry, wrong patient! A patient verification process is needed everywhere, not just at the bedside. Pharm Ther. 2014;39:535537.

10. Escrivá Gracia J, Brage Serrano R, Fernández Garrido J. Medication errors and drug knowledge gaps among critical-care nurses: a mixed multi-method study. BMC Health Serv Res. 2019:19:640.
11. Choi I, Lee S, Flynn L, Kim C, Lee S, Kim N, Suh D. Incidence and treatment costs attributable to medication errors in hospitalized patients. Res Soc Admin Pharm. 2016;12:428-437.

12. Ridley SA, Booth SA, Thompson CM, Intensive Care Society's Working Group on Adverse Incidents. Prescription errors in UK critical care units. Anaesthesia. 2004;59:1193-1200. 